\title{
Commentary
}

\section{COVID-19 pandemic: insights into human behaviour}

\author{
Anuradha Kunal Shah ${ }^{1 *}$, Prabhadevi Ravichandran'1, Prabhu Ravichandran²
}

\author{
${ }^{1}$ Department of Community Medicine, Seth GS Medical College and KEM Hospital, Mumbai, Maharashtra, India \\ ${ }^{2}$ Private practitioner, Tamil Nadu, India
}

Received: 19 July 2020

Accepted: 04 September 2020

\section{*Correspondence:}

Dr. Anuradha Kunal Shah,

E-mail: anuradha.moha@gmail.com

Copyright: (C) the author(s), publisher and licensee Medip Academy. This is an open-access article distributed under the terms of the Creative Commons Attribution Non-Commercial License, which permits unrestricted non-commercial use, distribution, and reproduction in any medium, provided the original work is properly cited.

\section{INTRODUCTION}

The novel coronavirus disease or COVID-19 that emerged at the end of December 2019 has affected people of many countries around the world. It has placed an overwhelming burden on health care systems and authorities. $^{1}$ Since there is no vaccine or definitive treatment yet, widespread social and behavioural changes are critical in reducing the transmission of the virus and mitigating the impact of COVID-19., ${ }^{1,2}$ The combined knowledge of social and behavioural sciences with the recommendations of epidemiologists and public health experts can help align human behaviour in a conducive manner. ${ }^{3}$

The knowledge about what drives behaviour and awareness of changes in these drivers is necessary. ${ }^{4,5}$ People's behaviour is influenced by societal norms, what they perceive that others are doing or what they think that others approve or disapprove of. ${ }^{5}$ These perceptions can often be inaccurate. People can underestimate healthpromoting behaviours (hand washing) and overestimate unhealthy behaviours. Public messages reinforcing positive (health promoting) norms can correct such misconceptions.

Here we have highlighted some of the commonly seen human behaviours during a pandemic crisis.

\section{Protective behaviour}

The coronavirus is novel and there is no vaccine or definitive treatment for it yet. The incidence and casefatality rates vary across countries and continents. This causes high uncertainty regarding the likelihood of contracting the disease. Thus, the knowledge of risk perceptions is critical for protective behavior. ${ }^{6}$ Preventive and protective behaviour during this pandemic includesregular hand washing/ sanitizing, avoid touching the face, disinfecting mobile phone screens, staying at home when sick, covering up while coughing, balanced diet, physical distancing, wearing of face mask, avoiding crowded places, homeopathic remedies, self -quarantine, socializing digitally, and many more. It is assumed that these actions are adopted by the people after estimating the risk, evaluating the costs and benefits of action, and then selecting an action that will provide them with desired results. ${ }^{6}$ It has been seen during the influenza pandemic (2009-2010) that uncertainty and perceived exaggeration led to a reduced likelihood of implementing the recommended behaviors. ${ }^{7,8}$ The stakeholders should identify and understand which of the protective measures are known by the people and which area there is a lack of information. Appropriate public messages can then be targeted at such behaviours.

\section{Social distancing}

It is one of the non-pharmaceutical public health interventions taken to prevent the spread of the virus and reduce transmission. It is seen that people respond more strongly to losses than gains, therefore telling people they could cause harm to others by going out can be more effective than telling them they're saving lives by staying home. $^{5}$

If many people are visibly social distancing, more are likely to follow but, social distancing is a largely unseen behavior. $^{9}$ 


\section{Health seeking behaviour}

As people perceive themselves as being at risk of infection or being infected, they will form an impression that they should get tested even if they have slightest of symptoms. Some may want to get tested even without symptoms. Such behaviour can overwhelm any health system and in a limited resource setting will affect the needier. It is therefore important that simple instructions are given to the community regarding this. For example, if you develop fever, cough and/or difficulty breathing, and have been in close contact with a person known to have COVID-19 or have recently travelled from an area with the ongoing spread of COVID-19, stay home and call your healthcare provider. Simple instructions when communicated repeatedly help the community in identifying their risk. ${ }^{5}$

\section{Discriminatory behaviour}

During pandemics, greater fear and perceived threat are associated with increased intolerance, discrimination, and violence against stigmatized groups. ${ }^{5}$ Various print media have reported that ethnic Asian people are experiencing physical attacks in predominantly white countries due to mischaracterizations of SARS-CoV-2 as the "Wuhan" or "Chinese virus". ${ }^{10}$ There have been incidences of stigmatization of certain religious groups for the spread of COVID-19 too. Therefore, this necessitates the creation of opportunities for reducing religious and ethnic conflicts. Harmonized efforts among individuals, public, and government highlighting the national and international co-operation can send signals of unity. ${ }^{11}$ The current pandemic has already utilized this to its benefit. India has supplied Hydroxychloroquine tablets to the USA. ${ }^{12}$ China is also helping other countries by providing test-kits and other medical supplies. ${ }^{13}$

\section{Misinformation}

During a pandemic, effective communication plays an important role. The onus is on public health departments to convey accurate and necessary information to the public since news channels and social media are flooded with constant amplified information. Misinformation is readily circulated and contributes to heightened fear and outrage among the general public. It can weaken any public health action and should be refuted. Easily understandable information should be disseminated by the public health authorities through accessible channels that the public trust and use..$^{5}$

\section{Psychological behaviour}

Anger, worry, and fear are the most common psychological responses. Many people are finding themselves in sudden forced proximity with their immediate family. People subjected to quarantine/selfisolation are at risk for confusion, anger, and emotional tendencies due to constant enduring by family members for weeks or months. Studies have reported that forced proximity is a risk factor for aggression and domestic violence. $^{5}$

People are also worried about getting infected in crowded places such as public transport, shops, or restaurants. Many are worrying about their jobs even in middle and high-income countries. ${ }^{14}$

It has also been reported that strong fear appeals produce the greatest behaviour change only when people feel a sense of efficacy. Strong fear appeals with low-efficacy messages produce the greatest levels of defensive responses..$^{5}$ The media reporting on COVID-19 is mainly negative, for example, the number of people infected/died as opposed to number recovered/mildly symptomatic. This may increase negative emotions and such as fear and can also lead to people committing suicide. However, fear of contracting the disease has made people stay indoors and limited the spread of the virus.

\section{Herd behaviour}

The most common herd behaviour experienced during the pandemic is "panic buying." It is a belief that, when in peril, people panic, especially in crowds. They start acting blindly and excessively out of self-preservation, potentially endangering the survival of all. This explains the notion of "panic buying."15 People stock up on supplies to prepare themselves for potential self-isolation. When people feel they do not have control over risk, their emotional response is heightened.

\section{CONCLUSION}

The current pandemic of COVID-19 is unprecedented but, the important lessons of public health measures and preventive actions are conventional. These are highly influenced by risk perception by the public, protective and preparedness behaviours, and effective communication. Adequate knowledge about what drives behaviour and ways to address misconceptions can better equip the authorities to deal with the pandemic crisis.

\section{REFERENCES}

1. Betsch C, Wieler LH, Habersaat K. Monitoring behavioural insights related to COVID-19. The Lancet. 2020;395(10232)1255-6.

2. WHO/Europe Coronavirus disease (COVID-19) outbreak- WHO tool for behavioural insights on COVID-19 Available at: http://www.euro.who.int/ en/health-topics/health-emergencies/coronaviruscovid-19/novel-coronavirus-2019-ncov-technicalguidance/who-tool-for-behavioural-insights-oncovid-19. Accessed on 27 April 2020.

3. Betsch C. How behavioural science data helps mitigate the COVID-19 crisis. Nat Hum Behav. 2020;4:438.

4. World Health Organization. Communicating risk in 
public health emergencies: a WHO guideline for emergency risk communication (ERC) policy and practice. Available at: https://www.who.int/riskcommunication/guidance/download/en/. Accessed on 27 April 2020.

5. Bavel JJ Van, Baicker K, Boggio P, Capraro V, Cichocka A, Crockett M, et al. Using social and behavioural science to support COVID-19 pandemic response. Nat Hum Behav. 2020;4:460-71.

6. Van der Pligt J. Risk Perception and Self-Protective Behavior. Eur Psychol. 1996;1(1):34-43.

7. Reintjes R, Das E, Klemm C, Richardus JH, Kebler V, Ahmad A. Pandemic public health paradox: time series analysis of the 2009-10 influenza a, H1N1 epidemiology, media attention, risk perception and public reactions in 5 European countries. PLoS One. 2016;11(3):e0151258.

8. Rubin GJ, Amlôt R, Page L, Wessely S. Public perceptions, anxiety, and behaviour change in relation to the swine flu outbreak: Cross sectional telephone survey. BMJ. 2009;339(7713):156.

9. European centre for disease prevention and control. Considerations relating to social distancing measures in response to the COVID-19 epidemic. Available at: https://www.ecdc.europa.eu/en/publicationsdata/considerations-relating-social-distancingmeasures-response-covid-19-second. Accessed on 27 April 2020.

10. Russell A. The Rise of Coronavirus hate crimes. Available at: https://www.newyorker.com/news/ letter-from-the-uk/the-rise-of-coronavirus-hatecrimes. Accessed on 27 April 2020.

11. Dovidio JF, Gaertner SL, Saguy T. Another view of we: Majority and minority group perspectives on a common ingroup identity. Eur Rev Soc Psychol. 2007; 18(1):296-330.

12. More than 29 million hydroxychloroquine doses bought by U.S. have come from India, says President Trump - The Hindu. Available at: https://www.the hindu.com/news/international/more-than-29-millionhydroxychloroquine-doses-bought-by-us-have-comefrom-india-says-president-trump/article 31286633. ece. Accessed on 27 April 2020.

13. Kuo L. China sends doctors and masks overseas as domestic coronavirus infections drop. Available at: https://www.theguardian.com/world/2020/mar/19/chi na-positions-itself-as-a-leader-in-tackling-thecoronavirus. Accessed on 27 April 2020.

14. Pakpour A, Griffiths M. The fear of COVID-19 and its role in preventive behaviors. J Concurr Disord. 2020;2(1):58-63.

15. Clarke L. Panic: myth or reality?. Contexts. 2002;1:21-6.

Cite this article as: Shah $\mathrm{AK}$, Ravichandran $\mathrm{P}$, Ravichandran P. COVID-19 pandemic: insights into human behaviour. Int J Community Med Public Health 2020;7:4213-5. 